\title{
Apatemyids (Mammalia, Apatotheria) from the middle Chadronian (late Eocene) of Sioux County, Nebraska, USA
}

\author{
Matthew A. Tornow and Tafline C. Arbor
}

\begin{abstract}
The Apatemyidae are a unique radiation of insectivorous mammals known from the Paleogene of North America, Europe, and India. Apatemyids are rare components of the faunas where they are found, and small sample sizes create difficulties in interpreting variation and establishing meaningful taxonomy. Despite disagreement regarding the number of genera and species, there is agreement that two apatemyid genera exist sequentially during the Eocene in North America. The genus Apatemys appears during the Wasatchian and persists through the Duchesnean, followed by Sinclairella, which persists from the Duchesnean through the Arikareean. Here, we describe apatemyid specimens collected from three sites in Sioux County, Nebraska, during field seasons from 2011-2016. All three localities include specimens of Sinclairella dakotensis, nearly doubling the number of known specimens of Sinclairella from Nebraska. In addition, one of these localities, the Whitehead Creek locality, includes two upper molars of a second apatemyid taxon that we assign to the genus Apatemys. Reevaluation of the apatemyid sample from the temporally and geographically proximate Raben Ranch locality suggests that one $\mathrm{m} 1$, previously assigned to Sinclairella, belongs to the same species of Apatemys represented at Whitehead Creek. When taken in conjunction with a single M2 from Chadronian-age deposits of the Cypress Hills Formation, Saskatchewan, these new specimens indicate that at least two species of Apatemys persist into the late Eocene of the Great Plains Faunal Province. Moreover, they add to a growing list of taxa that persist as relicts in the Chadronian of the Great Plains after extinction elsewhere.
\end{abstract}

Matthew A. Tornow. Department of Anthropology, Saint Cloud State University, 720 4th Avenue South, Saint Cloud, Minnesota 56301, USA. matornow@stcloudstate.edu

Tafline C. Arbor. Division of Biomedical Sciences, Marian University College of Osteopathic Medicine, 3200 Cold Spring Road, Indianapolis, Indiana 46222, USA. tarbor@marian.edu

Keywords: Apatemyidae; Sinclairella; Apatemys; Chadronian; late Eocene; Nebraska

Tornow, Matthew A. and Arbor, Tafline C. 2017. Apatemyids (Mammalia, Apatotheria) from the middle Chadronian (late Eocene) of Sioux County, Nebraska, USA. Palaeontologia Electronica 20.1.9A: 1-16

palaeo-electronica.org/content/2017/1770-apatemyids-from-nebraska 


\section{INTRODUCTION}

Apatemyids are a family of specialized mammals found in Tertiary deposits of North America (Gunnell et al., 2008; Czaplewski and Morgan, 2015), western Europe (Russell et al., 1979; Marandat, 1989; Estravis, 2000), and India (Bajpai et al., 2005). Most apatemyid taxa are characterized by a suite of dental characters, including an enlarged, vertically-oriented first upper incisor (I1), a large and procumbent first lower incisor (i1), an elongate and blade-like second lower premolar (p2), a reduced paraconid on the lower molars, and the presence of an additional antero-buccal cusp on the lower molars. The most marked postcranial adaptation is a unique elongation of the second and third digits that are morphologically, and presumably functionally, similar to the elongate fourth digit of the genus Dactylopsila and third and fourth digits of the genus Daubentonia that are used to forage for wood-boring insects (Flannery, 1994; von Koenigswald and Schierning, 1987; von Koenigswald et al., 2005; Soligo, 2005).

Although the Apatemyidae are geographically widespread, apatemyid specimens are relatively rare and comprise only small percentages of the faunas within which they are found (McKenna, 1963; Czaplewski and Morgan, 2015). This makes it difficult to evaluate within-taxon variation and establish meaningful diagnoses for apatemyid subtaxa (McKenna, 1963; West, 1973; Bown and Shankler, 1982). Whereas there is some disagreement regarding the number of apatemyid genera and species (West, 1973; Gingerich, 1982; Bown and Shankler, 1982), there is general consensus that there are five North American genera: Jepsenella, Unuchinia, Labidolemur, Apatemys, and Sinclairella (Gunnell et al., 2008). The genera Jepsenella and Unuchinia are known from Paleocene deposits, Labidolemur is represented in Paleocene and Eocene deposits (Silcox et al., 2010), Apatemys is represented in Eocene deposits (West, 1973; Bown and Shankler, 1982; Gunnell et al., 2008; Beard and Dawson, 2009), and Sinclairella is represented in Eocene and Oligocene deposits (Jepsen, 1934; Clemens, 1964; West, 1973; Ostrander, 1980, 1987; Gunnell et al., 2008; Cavin and Samuels, 2012; Czaplewski and Morgan, 2015).

Previously, apatemyids have been reported from three Chadronian-age localities in Sioux County Nebraska (Figure 1). Clemens (1964) described seven molars of Sinclairella dakotensis

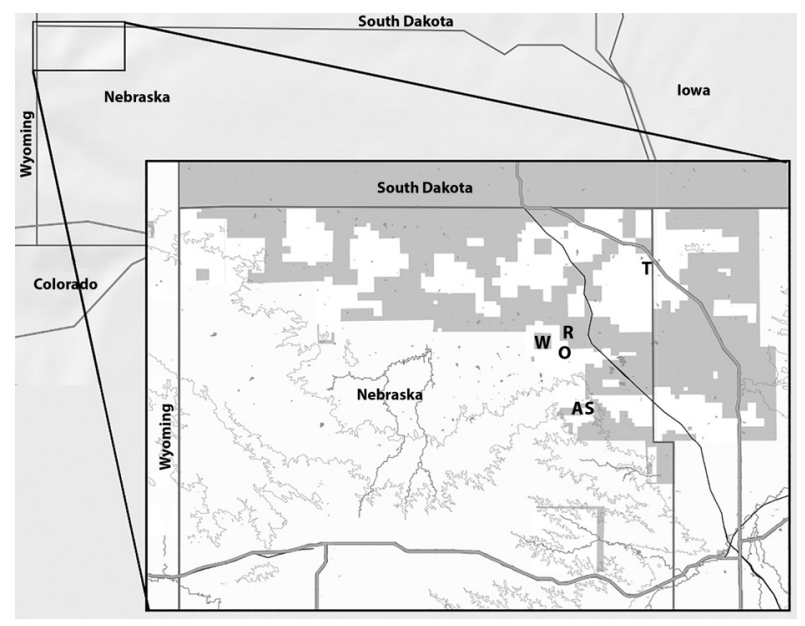

FIGURE 1. Apatemyid localities in Sioux County, Nebraska. R: Raben Ranch locality of Ostrander (1980, 1987); A: Anthill locality of Hough and Alf (1956); T: Twin Buttes locality of Ostrander (1985); S: Sand Creek locality; O: Orella Road locality; W: Whitehead Creek locality.

that were collected a decade earlier from a series of anthills in Section 26 T33N, R53W (Hough and Alf, 1956; Alf, 1962); and Ostrander (1980, 1987) described a complete lower premolar (p2) of $S$. dakotensis and allocated six additional teeth to the species in his discussion of the Raben Ranch Locality (Section 32 T34N, R53W). Ostrander (1985) included Sinclairella dakotensis in the faunal list for the Twin Buttes locality, though no specimen allocations or descriptions were provided.

The anthill fauna from which Clemens (1964) described specimens of Sinclairella dakotensis was originally described by Hough and Alf (1956). Although located on top of exposures of the Chadron Formation, these authors demonstrated that this anthill fauna contained a mix of Chadronian taxa (e.g., cylindrodontids) and Orellan taxa (e.g., genus Eumys). Most likely, this composition resulted from redeposited Orellan-age sediments of the Brule Formation becoming incorporated into the anthills at this locality (Guthrie and Allen, 1974; Ostrander, 1980; Korth, 1992). In fact, Ostrander (1980) cited the presence of Eumys in this anthill fauna to suggest an older age for the Raben Ranch fauna, from which the genus Eumys was unknown. Whereas Clemens (1964) sited a personal communication with Alf that it was unlikely that the anthills contained younger specimens, he described extensive abrasion for one specimen of Sinclairella. Abrasion has been used to identify reworked, Orellan specimens at this locality (Guthrie and Allen, 1974; Korth, 1992). Thus, it is possible that some 
of these specimens of Sinclairella were redeposited from younger, Orellan-age deposits. To date, only the apatemyid genus Sinclairella is known from Chadronian localities in Sioux County, Nebraska.

Herein, we report the recovery of 14 isolated apatemyid teeth from Sioux County, Nebraska. Whereas 12 of these teeth are attributed to Sinclairella dakotensis, the remaining two specimens are assigned to the genus Apatemys, thus extending the geographic distribution of this genus during the late Eocene.

\section{GEOLOGICAL CONTEXT}

The apatemyids described here were collected from three different localities within Sioux County, Nebraska (Figure 1): the Sand Creek, Orella Road, and Whitehead Creek localities. University of Montana Paleontology Center (UMPC) locality number V6316, the Sand Creek Locality, consists of a series of anthills in Section 25 T33N R53W. These anthills sit at the contact between exposures of the middle Chadronian, Peanut Peak Member of the Chadron Formation, and the undifferentiated Holocene-Pleistocene deposits that cap the Chadron Formation at this locality (LaGarry and LaGarry, 1997). Evaluation of the fauna from this locality demonstrates a similar fauna to that described by Hough and Alf (1956) for their anthill locality located one section west in which both Chadronian taxa (e.g., cylindrodontids) and Orellan taxa (e.g., genus Eumys) are present. The proximity of the Sand Creek Locality to that identified by Hough and Alf, in conjunction with a similar, mixed Orellan/Chadronian fauna suggests that the anthills of locality V6316 are composed of the same sediments. Whereas much of the fauna from these anthills overlaps in age with the other two UMPC localities, the presence of Orellan-age taxa indicates a broader temporal sample in the Sand Creek anthills than those found in the middle Chadronian Orella Road and Whitehead Creek localities.

The Orella Road Locality (V6324) consists of a series of anthills south of Orella Road in Section $31 \mathrm{~T} 34 \mathrm{~N} \mathrm{R} 53 \mathrm{~W}$. These anthills are located on the contact between exposures of Chadron Formation and undifferentiated Holocene-Pleistocene sediments (LaGarry and LaGarry, 1997). Like the Sand Creek Locality, the column of Chadron Formation at Orella Road consists of exposures of the Peanut Peak Member. The Orella Road site differs from the Sand Creek Locality and Hough and Alf's
(1956) anthill locality in its lack of Orellan-age fossils.

The Whitehead Creek Locality (V6335) is composed of a series of low-lying exposures of the Chadron Formation, as well as associated anthills located near the boundary of Section 31 T34N R53W and Section 36 T34N R54W. Whereas some collection of in situ exposures of the Peanut Peak Member of the Chadron Formation was performed; collection at this locality was also performed on stratigraphically accumulated deposits with very fine layers of coarse sands, silts, pebbles and rip-up clasts consistent with alluvial deposition. Comparisons of the constituent layers of this alluvium with exposures, drainages, and runnels in the immediate vicinity demonstrate that the strata found in exposures at this locality are composed of materials found within the surrounding Chadron Formation exposures and are most consistent with the flats formed where runnels converge at the bases of exposures. In the locality where subsurface quarrying was performed, the first 10 to $15 \mathrm{~cm}$ consist of coarse-grained sandstone consistent with channel sands of the Peanut Peak Member. These sands are accompanied by larger, consolidated blocks of sandstone, suggesting that these deposits were not transported very far; most likely, these sands eroded in situ. The adherence of sandstone consistent with channel sands of the Peanut Peak Member taken in conjunction with the exclusivity of Peanut Peak exposures in the immediate vicinity (LaGarry and LaGarry, 1997) implies that all fossils from the collection area can be assigned to the Peanut Peak Member. The buff colored exposures of the Whitehead Creek Locality are stratigraphically above the olive green exposures of Peanut Peak that occur at the Chamberlain Pass-Chadron Formation contact approximately 1 mile to the southwest. Moreover, the exposures range from at least $1 \mathrm{~m}$ to $3 \mathrm{~m}$ below the Peanut Peak Member-Big Cottonwood Creek Member contact. This indicates that the Whitehead Creek Locality is at least as old as the Raben Ranch Locality, which spans the contact between these two members (Prothero, 1996a; Terry, 1998). Correlations of the Raben Ranch Local Fauna with those of Ashes B and F at Flagstaff Rim, Wyoming, indicate that the Raben Ranch Locality falls within Chrons C16n.1-C15r (35.6-35 mya) (Emry, 1992; Prothero and Swisher, 1992; Prothero, 1996a), establishing a date older than 35 mya for the Whitehead Creek Locality. 


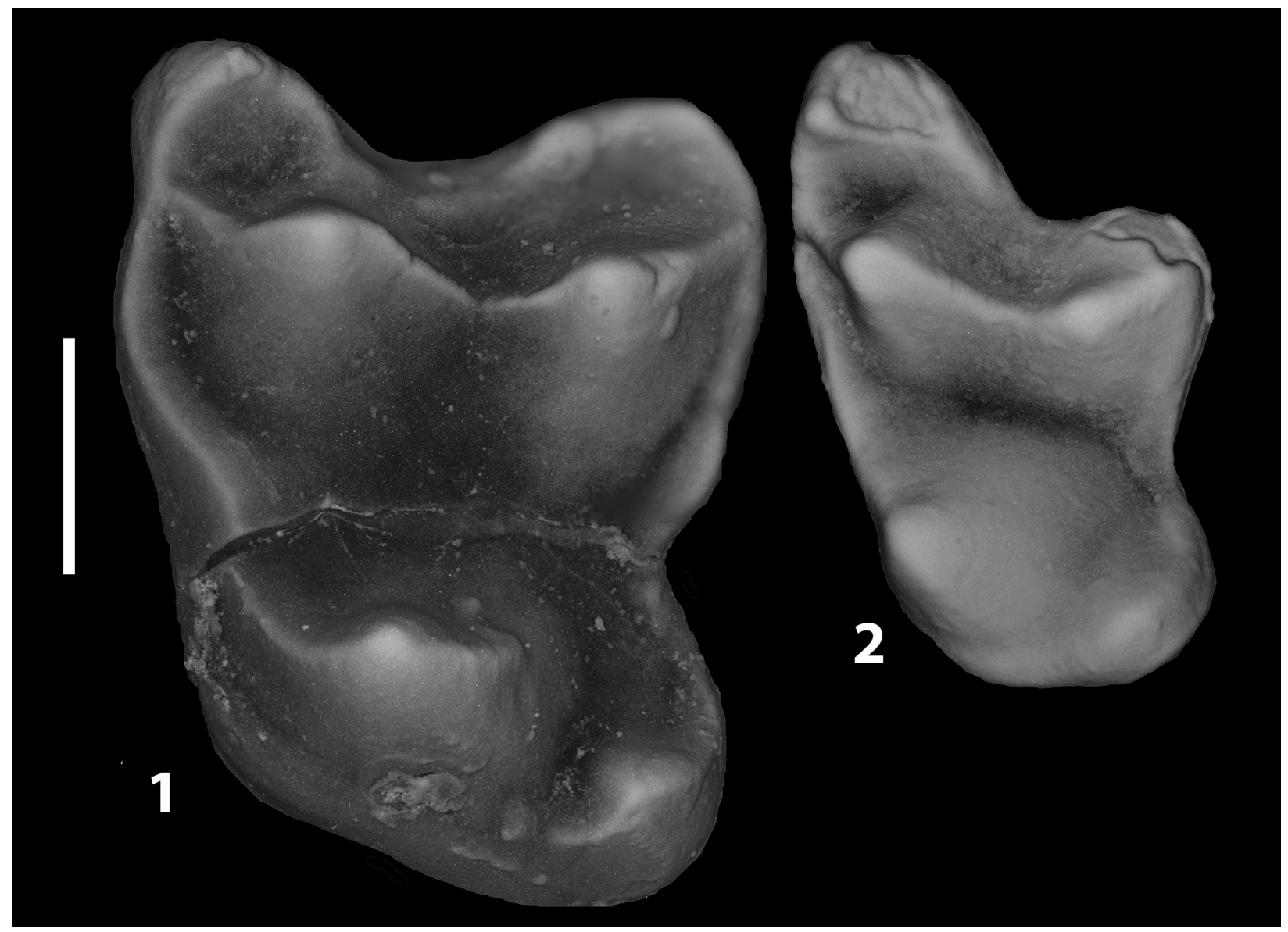

FIGURE 2. Apatemys specimens from the Whitehead Creek locality. 1, left M2 (UMPC 14190) and 2, left M3 (UMPC 14191). Teeth are shown in occlusal view. Scale is approximately $1 \mathrm{~mm}$.

\section{MATERIALS AND METHODS}

Fossils from all three localities were collected from harvester ant mounds using whisk brooms and dust pans. Additional collection at the Whitehead Creek locality was performed using surface sweeps and a series of small $\left(<1 \mathrm{~m}^{2}\right)$ subsurface samples. Samples collected through surface sweeping and subsurface excavation were screenwashed through sieves down to $0.5 \mathrm{~mm}$. In order to avoid cross contamination between sampling areas within the Whitehead Creek locality, sieves were cleaned using a combination of water, compressed air, and an ultrasonic cleaner. In no instance did cleaning effectively remove all residual matrix from the sieves, thus, following cleaning, sieves were visually inspected under a binocular microscope to confirm that no fossils were present. Once samples were collected and size sorted, they were probed under binocular microscopes to recover fossils. Thus far, all apatemyid specimens from the Whitehead Creek locality have been recovered by sweeping surface exposures and collecting from anthills, but field sampling at this locality is ongoing.

\section{Institutional Abbreviations}

UMPC, University of Montana Paleontology Center, The University of Montana, Missoula, Montana, USA; SDSM, Museum of Geology, South Dakota School of Mines and Technology, Rapid City, South Dakota, USA; RSM, Royal Saskatchewan Museum, Regina, Saskatchewan, Canada; AMNH, American Museum of Natural History, New York, New York, USA; LACM (CIT), Los Angeles County Museum (California Institute of Technology), Los Angeles, California, USA.

\section{SYSTEMATIC PALEONTOLOGY}

Order APATOTHERIA Scott and Jepsen, 1936

Family APATEMYIDAE Matthew, 1909

Genus APATEMYS Marsh, 1872 


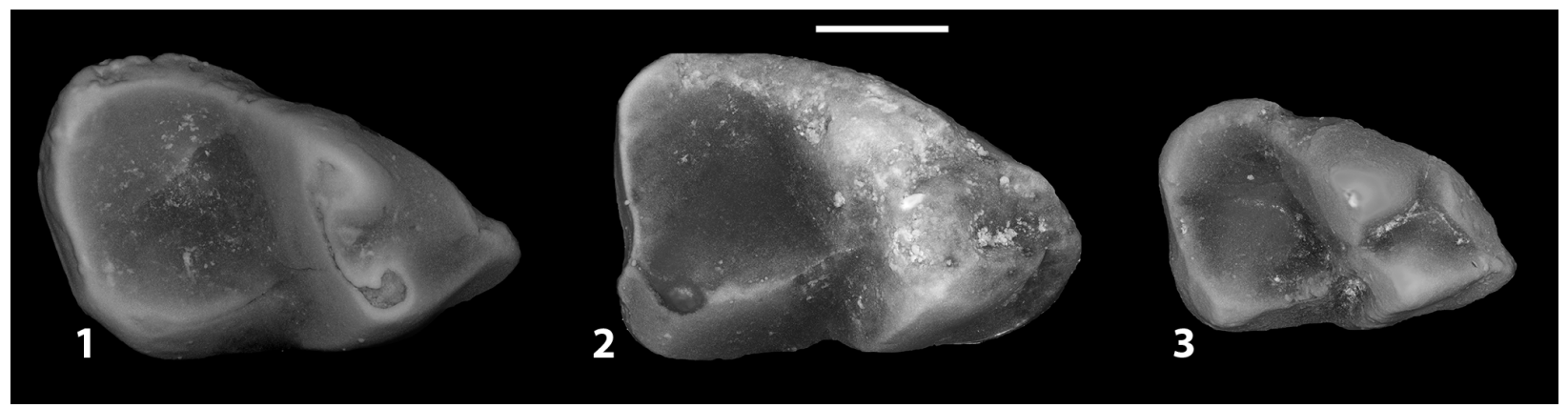

FIGURE 3. Apatemyid first molars from Raben Ranch. 1 and 2, right m1s of Sinclairella dakotensis (SDSM 10241) and 3, right $\mathrm{m} 1$ of Apatemys sp. (SDSM 10242). Teeth are shown in occlusal view. Scale is approximately $1 \mathrm{~mm}$.

Apatemys sp. aff. A. downsi Gazin, 1958

Figures 2 and 3.3, Tables 1 and 2

Referred specimens. Left M2, UMPC 14190; left M3, UMPC 14191; right m1, SDSM 10242.

Horizon and locality. UMPC Locality \# MV 6335 "Whitehead Creek", UMPC 14190, 14191; SDSM Locality \# V772-A "Raben Ranch", SDSM 10242. Middle Chadronian Peanut Peak Member, Chadron Formation.

Description. UMPC 14190 is a left M2 that exhibits a crack extending across the midline of the tooth from the anterior to the posterior margin (Figure 2.1). Otherwise, the tooth is in excellent condition. It displays minimal wear and all crown features are clearly visible. Of the three cusps that comprise the trigon, the protocone is slightly larger than the two, subequal, buccal cusps. The protocone is conical, although the cusp appears slightly bucco-lingually compressed given the presence of a short, stout postprotocrista that decreases in height as it is traced posteriorly from the apex of the protocone. The paracone and metacone are conical. The anterior margin of the trigon is closed by a strong preprotocrista that runs antero-buccally along the anterior edge of the tooth crown from the tip of the protocone to a point directly anterior to the paracone, where it joins with a preparacrista that runs in an anterior and slightly buccal direction from the paracone. A weak paraconule arises from a modest swelling of the preprotocrista lingual and slightly anterior to the paracone. Running posteriorly from the paracone is a well-formed postparacrista. This crest joins with an equally welldeveloped premetacrista on the midline of the tooth to form a deep "v." The postmetacrista travels postero-buccally from the tip of the metacone to the posterior margin of the tooth. The buccal margin of the tooth is characterized by strong parastylar and metastylar lobes. These stylar developments are separated by a deep ectoflexus.

TABLE 1. Upper molar metrics $(\mathrm{mm})$ for apatemyids (Apatemys and Sinclairella) from Sioux County, Nebraska. Sources: 1, this study; 2, Clemens (1964); and 3, Ostrander (1987). Abbreviations: L, maximum anterior-posterior length; $W$, maximum transverse width.

\begin{tabular}{lllcccc}
\hline $\begin{array}{c}\text { Specimen } \\
\text { number }\end{array}$ & \multicolumn{1}{c}{ Locality } & \multicolumn{1}{c}{ Species } & Tooth & L & W & Source \\
\hline UMPC 13937 & Sand Creek & S. dakotensis & M1 & 4.1 & 3.69 & 1 \\
UMPC 14860 & Whitehead Creek & S. dakotensis & M1 & 3.68 & 3.43 & 1 \\
RAM 381 & "anthills" sec. 26 & S. dakotensis & M1 & 4.1 & 3.5 & 2 \\
UMPC 14862 & Sand Creek & S. dakotensis & M2 & 3.73 & 4.63 & 1 \\
RAM 1674 & "anthills" sec. 26 & S. dakotensis & M2 & 3.4 & 4.2 & 2 \\
UMPC 14190 & Whitehead Creek & Apatemys sp. & M2 & 2.8 & 3.3 & 1 \\
UMPC 14863 & Sand Creek & S. dakotensis & M3 & 3.51 & 4.89 & 1 \\
UMPC 14864 & Sand Creek & S. dakotensis & M3 & $2.74 a$ & 3.4 a & 1 \\
UMPC 14191 & Whitehead Creek & Apatemys sp. & M3 & 1.8 & 2.8 & 1 \\
\hline
\end{tabular}

aApproximate measurement based on damaged specimen. 
TABLE 2. Lower molar metrics $(\mathrm{mm})$ for apatemyids (Apatemys and Sinclairella) from Sioux County, Nebraska. Sources: 1, this study; 2, Clemens (1964); 3, Ostrander (1987). Abbreviations: L, maximum anterior-posterior length; Tri W, maximum transverse width across the trigonid; Tal W, maximum transverse width across the talonid.

\begin{tabular}{|c|c|c|c|c|c|c|c|}
\hline $\begin{array}{l}\text { Specimen } \\
\text { number }\end{array}$ & Locality & Species & Tooth & $\mathbf{L}$ & Tri W & Tal W & Source \\
\hline UMPC 14861 & Orella Road & S. dakotensis & $\mathrm{m} 1$ & 3.48 & 1.88 & 2.24 & 1 \\
\hline UMPC 13938 & Sand Creek & S. dakotensis & $\mathrm{m} 1$ & 3.44 & 1.79 & 2.07 & 1 \\
\hline UMPC 14270 & Whitehead Creek & S. dakotensis & $\mathrm{m} 1$ & 3.45 & 1.57 & 2.08 & 1 \\
\hline RAM 1000 & “anthills" sec. 26 & S. dakotensis & $\mathrm{m} 1$ & 3.5 & * & 2.2 & 2 \\
\hline SDSM 10241-a & Raben Ranch & S. dakotensis & $\mathrm{m} 1$ & 3.51 & 2.01 & 2.4 & 3 \\
\hline SDSM 10241-b & Raben Ranch & S. dakotensis & $\mathrm{m} 1$ & 3.61 & 1.96 & 2.36 & 3 \\
\hline SDSM 10242 & Raben Ranch & Apatemys sp. & $\mathrm{m} 1$ & 2.62 & 1.54 & 1.72 & 3 \\
\hline UMPC 13601 & Sand Creek & S. dakotensis & $\mathrm{m} 2$ & $3.26^{a}$ & $1.84 \mathrm{a}$ & $1.98^{a}$ & 1 \\
\hline UMPC 13869 & Sand Creek & S. dakotensis & $\mathrm{m} 2$ & 3.5 & 2.74 & 2.59 & 1 \\
\hline UMPC 14866 & Whitehead Creek & S. dakotensis & $\mathrm{m} 2$ & 3.65 & 2.42 & 2.36 & 1 \\
\hline UMPC 14865 & Whitehead Creek & S. dakotensis & $\mathrm{m} 2$ & * & 2.3 & * & 1 \\
\hline RAM 598 & "anthills" sec. 26 & S. dakotensis & $\mathrm{m} 2$ & 3.8 & * & 2.6 & 2 \\
\hline RAM 1001 & "anthills" sec. 26 & S. dakotensis & $\mathrm{m} 2$ & 3.6 & * & 2.6 & 2 \\
\hline RAM 1079 & "anthills" sec. 26 & S. dakotensis & $\mathrm{m} 2$ & 4 & * & 2.8 & 2 \\
\hline RAM 3013 & "anthills" sec. 26 & S. dakotensis & $\mathrm{m} 2$ & 3.6 & * & 2.8 & 2 \\
\hline SDSM 10243 & Raben Ranch & S. dakotensis & $\mathrm{m} 2$ & 4.07 & * & 3.05 & 3 \\
\hline SDSM 10245 & Raben Ranch & S. dakotensis & m3 & 6.16 & 2.82 & 2.62 & 3 \\
\hline
\end{tabular}

*Measurement not available. Clemens (1964) provided only length and maximum width. aApproximate measurement based on damaged specimen.

There is a large talon heel extending off of the postero-lingual margin of the M2 crown, extending slightly more lingually and posteriorly than the protocone and metacone, respectively, to give the posterior margin of the tooth a waisted appearance. A small, but prominent hypocone arises from the postero-lingual corner of the talon. The hypocone is slightly elongated, running diagonally across the talon in an antero-lingual to postero-buccal direction.

On the M3 (UMPC 14191, Figure 2.2) the anteriorly-seated protocone is the largest of the trigon cusps in volume, and it is subequal in height to the paracone. The paracone is slightly larger than the metacone in both volume and height. As is the case with $\mathrm{M} 2$ the preprotocrista of M3 runs anterobuccally from the tip of the protocone along the anterior edge of the tooth crown. However, on M3 this crest stops short of the preparacrista, leaving the trigon basin open along its antero-buccal corner between the lingual margin of the paracone and the anterior border of the tooth crown. The preparacrista runs anteriorly from the paracone to the anterior edge of the tooth where, with the paracone, it forms the lingual margin of a large, antero-buccally extending parastylar lobe. The postparacrista is somewhat longer than the premetacrista, and the two crests meet to form a broad, shallow " $v$ " posterior to the midline of the tooth. The postmetacrista runs from the metacone to the posterior margin of the tooth. The metastylar lobe is considerably smaller than is seen on M2, and, subsequently, the anterior border of the ectoflexus is longer than the posterior border.

As is the case with $M 2$, there is a prominent talon lobe extending postero-lingually from the protocone on M3. Although less prominent on M3, the posterior extension of this lobe creates a waisted appearance of the posterior margin of the tooth similar to the condition expressed on M2. A small rise, suggestive of a hypocone, occupies the postero-lingual corner of the talon.

SDSM 10242 is a complete right $\mathrm{m} 1$ with minor enamel damage on the lingual margin of the tooth between the metaconid and entoconid (Figure 3.3). The trigonid is antero-posteriorly elongate 
and narrows anteriorly. The protoconid and metaconid are subequal and conical. The metaconid sits postero-lingual to the protoconid, thus giving the posterior trigonid wall (i.e., postvallid) an oblique orientation. The postmetacristid joins with the postprotocristid at the midpoint of the tooth to form a u-shaped notch that runs approximately one-third of the depth of the postvallid. Directly anterior to the metaconid is a small, but discernible paraconid. A prominent crest runs anteriorly from the apex of the protoconid to the antero-buccal corner of the tooth where it swells into a minute antero-buccal cusp.

The $\mathrm{m} 1$ talonid is broader than the trigonid. The postero-buccal corner of the tooth is marked by a conical hypoconid. The cristid obliqua runs antero-lingually in a straight line from the hypoconid to the posterior margin of the protoconid. Buccal to the junction of the cristid obliqua and the protoconid is a marked hypoflexid. The talonid is closed posteriorly by an arcuate postcristid. The hypoconulid and entoconid are suggested by two swellings on this posterior crest, along the midline of the tooth and at the postero-lingual corner of the tooth, respectively.

Remarks. The genus Apatemys is known from the Wasatchian (e.g., Simpson, 1954; Bown and Shankler, 1982), Bridgerian (e.g., West, 1973; Gunnell, 1998), and Uintan (e.g., Prothero, 1996b) of the Rocky Mountains Faunal Province. Beyond the Rocky Mountains, the genus is known in North America from the Wasatchian of Mississippi (Beard and Dawson, 2001, 2009), the Uintan of California (Gazin, 1958; Golz and Lillegraven, 1977; Walsh, 1991), and the Uintan (Storer, 1984), Duchesnean (Storer, 1987), and Chadronian (Storer, 1996; Meyer, 2007) of Saskatchewan. In Europe, Apatemys is known from the Sparnacian of France (Russell et al., 1979; Marandat, 1989), Belgium (Russell et al., 1979), and Portugal (Estravis, 2000). Although widely known, Apatemys is a rare component of the faunas from which it is known. Diagnoses of Apatemys species (e.g., McKenna, 1963; West, 1973; Bown and Shankler, 1982) overwhelmingly consist of characteristics of the lower premolars (e.g., McKenna, 1963), overall size (e.g., Robinson, 1966; West, 1973), and mandibular characteristics (e.g., McKenna, 1963). Few discussions of the genus (e.g., Beard and Dawson, 2009) assign upper teeth to the species level, and none provide detailed descriptions of the $\mathrm{m} 1$. The addition of these two middle Chadronian upper molars of Apatemys from the Whitehead Creek Local Fauna of northwestern Nebraska and attribu- tion of a lower molar from Raben Ranch, extends the geographic distribution of this genus during the late Eocene and adds to the range of known intrageneric variation within the genus Apatemys.

Whereas the genus Sinclairella is known from the research area, the two upper molar specimens from Whitehead Creek are attributed to the genus Apatemys on the basis of a suite of characters outlined by West and Atkins (1970). Both specimens exhibit more well-developed, parastylar and, in the case of M2, metastylar lobes than are seen in the corresponding teeth of Sinclairella, and the ectoflexus is more pronounced on each when compared with Sinclairella. The specimens of Apatemys exhibit reduced hypocones (particularly on M2) when compared with Sinclairella, thus resulting in a more triangular occlusal outline. The teeth here attributed to the genus Apatemys are also considerably smaller than the corresponding teeth in Sinclairella dakotensis (Table 1), the only other apatemyid taxon known from these deposits. Instead, the teeth being assigned to Apatemys are closer in size to Sinclairella simplicidens from the Arikareean of Florida (Czeplewski and Morgan, $2015)$ than to $S$. dakotensis. Morphologically, however, in their possession of marked stylar developments and the accompanying pronounced ectoflexus, the Whitehead Creek specimens diverge even further from the simplified teeth of $S$. simplicidens than they do from the older species, S. dakotensis.

The Whitehead Creek M2 exhibits an intermediate morphology between a Bridgerian apatemyid specimen (AMNH 56046) from Tabernacle Butte, Wyoming, described as Apatemys sp. by West and Atkins (1970) and an M2 from Chadronian-age deposits of the Cypress Hills Formation, Saskatchewan (RSM P2374.006) attributed to Apatemys sp. (Storer, 1996; described by Meyer, 2007). It is similar to both of the aforementioned specimens in possessing well-developed, large parastylar and metastylar lobes that are separated by a pronounced ectoflexus. However, the Whitehead creek specimen differs from the Tabernacle Butte, Wyoming, specimen in possessing more equally proportioned stylar lobes, the parastyle being relatively wider with less buccal extension. In this respect, the specimen described herein appears to be more similar to the M2 from Saskatchewan (Meyer, 2007, figure 5.8). The talon lobe is welldeveloped compared to Bridger specimens, albeit less so than that of the Chadronian specimen from Saskatchewan in which the talon lobe exhibits greater lingual extension. The hypocone is not as 


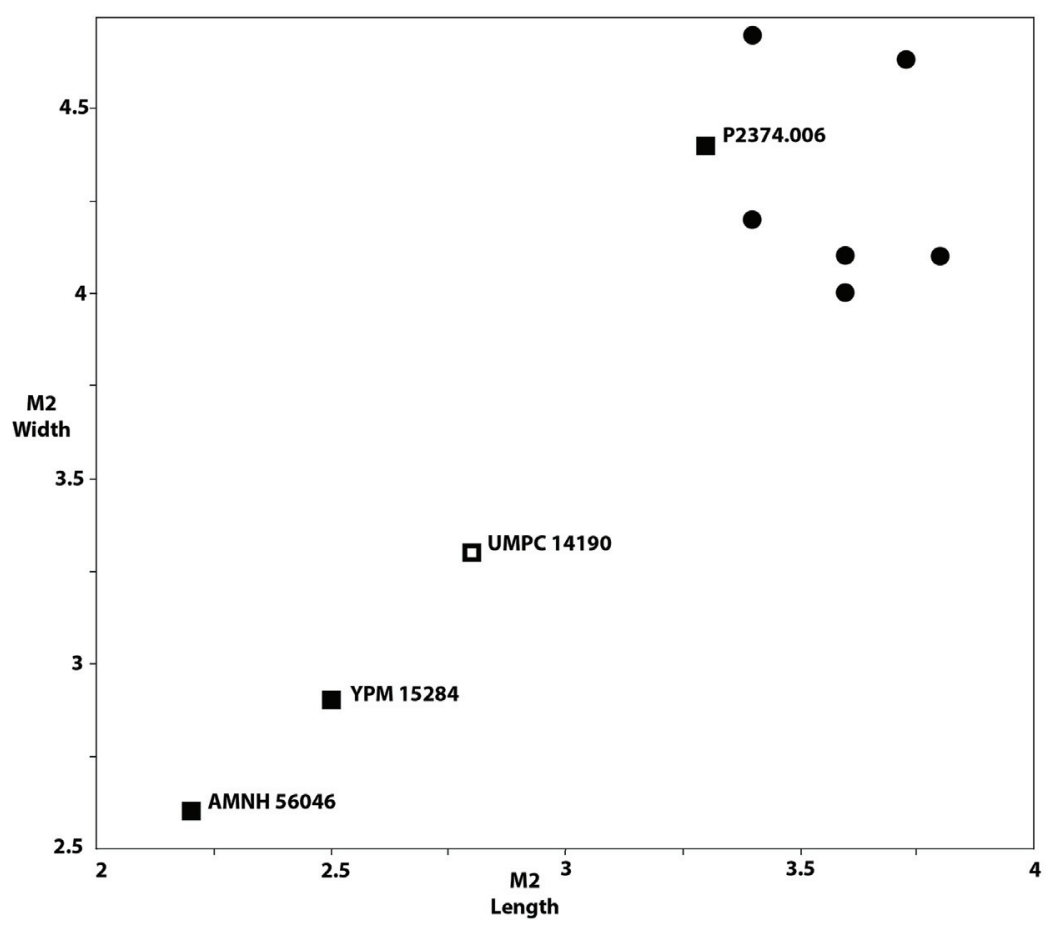

FIGURE 4. Plot of apatemyid M2 width $x$ length. Circles indicate Sinclairella dakotensis specimens. Squares indicate Apatemys specimens. The open square indicates the Whitehead Creek specimen described in this study. Data for AMNH 56046 and YPM 15284 are from West and Atkins (1970). Data for (RSM) P2374.006 are from Meyer (2007). Sinclairella data come from Clemens (1964), Cavin and Samuels (2012), and this study.

well developed in the Whitehead Creek M2 as it is in the specimen from Saskatchewan. In this feature, the small crestiform hypocone is more similar to the condition found in Bridgerian specimens attributed to Apatemys (West and Atkins, 1970). The Nebraska specimen is also intermediate in size between early and middle Eocene Apatemys bellus and the larger, Chadronian-age specimen from Cypress Hills (Figure 4).

The M3 (UCMP 14191) is considerably smaller than the M2. Whereas the antero-posteriorly short dimension of the M3 results in a tooth that is relatively more transverse than is the case for $M 2$, the tooth is absolutely narrower than M2 and thus significantly reduced when compared with associated Apatemys M2-3 (West, 1973). Whereas the size discrepancy between the Nebraska specimens does fall within the range of size differences (largest M2s, smallest M3s) for isolated Apatemys bellus specimens identified by West (1973), the taxonomic allocation of these specimens is disputed (Bown and Shankler, 1982). Thus, the size discrepancy between the Whitehead Creek M2 and M3 is likely greater than that for known species of Apatemys.
Ostrander's $(1980,1987)$ discussion of SDSM 10242, an $\mathrm{m} 1$ from the Raben Ranch local fauna, did not provide a detailed specimen description. He noted the small size of this specimen but emphasized the small sample size and resulting lack of knowledge of intraspecific variation for Sinclairella dakotensis in assigning this tooth to that species. Figure 5 illustrates that SDSM 10242 is considerably smaller than known $S$. dakotensis $\mathrm{m} 1 \mathrm{~s}$ from Sioux County, and that the Raben Ranch $\mathrm{m} 1$ is consistent with an apatemyid of the size represented by the M2 from Whitehead Creek (UMPC 14190), here attributed to Apatemys.

Whereas the general structure of the Raben Ranch $\mathrm{m} 1$ is similar to that of Sinclairella, it differs in features that more closely align with the morphology of Apatemys. In the trigonid, SDSM 10242 has a larger paraconid and a smaller antero-buccal cusp than is seen in Sinclairella specimens from Sioux County, Nebraska (see Figures 3.1-2, 6.8, and 6.11). Taken in conjunction with a relatively shorter crest running anteriorly from the protoconid, the difference in cusp proportions results in a trigonid that is relatively shorter antero-posteriorly and broader bucco-lingually and gives the trigonid 


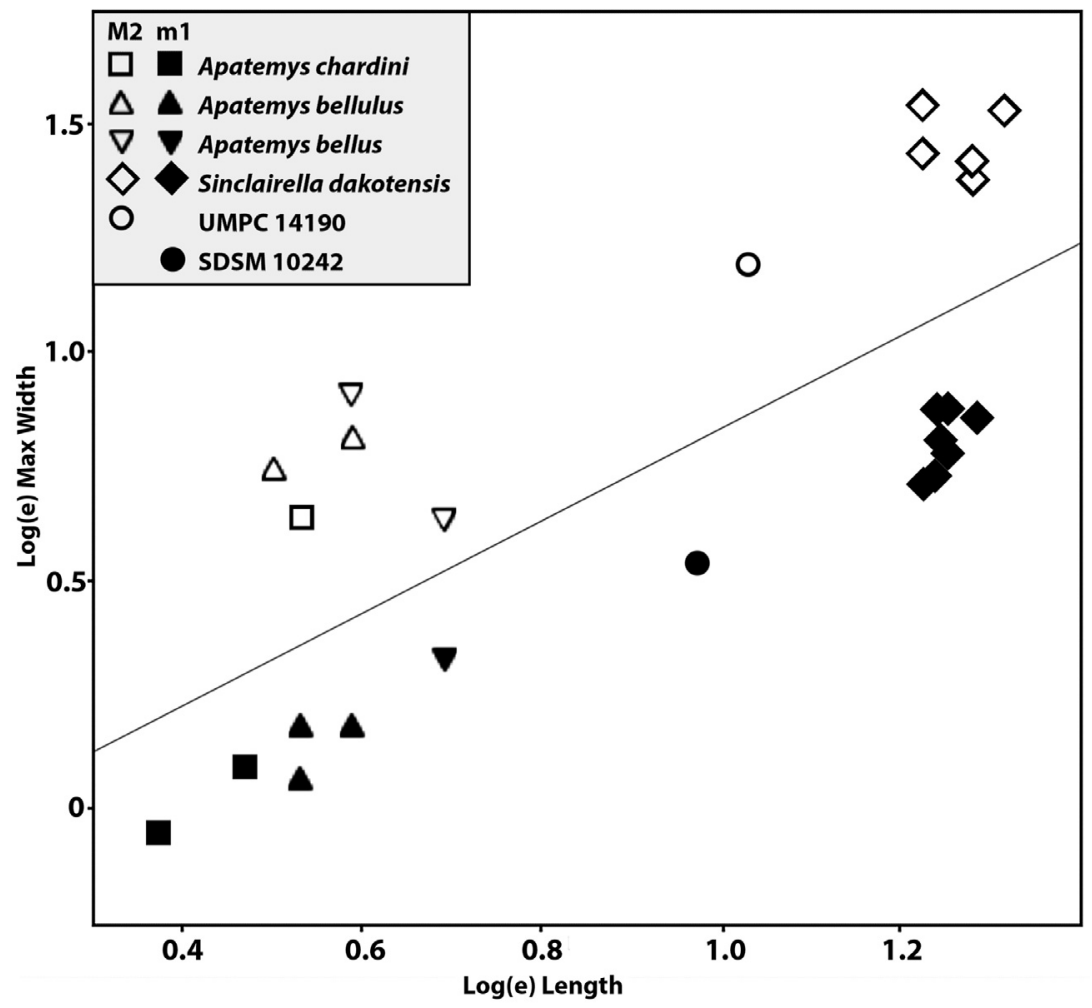

FIGURE 5. Plot of natural log width $x$ length of M2, open symbols above diagonal, and m1, solid symbols below diagonal from different apatemyid species, the M2 from Whitehead Creek (UMPC 14190), and the m1 from Raben Ranch (SDSM 10242). Note the compatible size relationship between the specimens from the Chadronian of Sioux County, Nebraska (circles). Data are compiled from the following sources: Apatemys chardini (Gingerich, 1982; Ma, 1998), $A$. bellulus (Gazin, 1958; Ma, 1998), A. bellus (Gazin, 1958; West, 1973; Ma, 1998), Sinclairella dakotensis (Clemens, 1964; Ostrander, 1987; Cavin and Samuels, 2012; this study).

a more rhomboidal appearance than is seen in the $\mathrm{m} 1$ of Sinclairella. Distally, the talonid cusps of SDSM 10242 are better developed than they are in specimens of Sinclairella. The hypoconid of SDSM 10242 is more conical, and, when combined with a straighter cristid obliqua, results in a more angular postero-buccal corner of the tooth. Although tiny, the hypoconulid and entoconid are visible in SDSM 10242, while these cusps are not clearly discernible in specimens of Sinclairella from Nebraska. The presence of comparably-sized upper molars of Apatemys from a locality that is close to Raben Ranch, both geographically and temporally, combined with the suite of Apatemys-like characteristics, demonstrate that SDSM 10242 is best assigned to the genus Apatemys.

Assigning the Nebraska Apatemys specimens to any species is hindered by the lack of diagnostic features of M2, M3, and $m 1$ for larger species of Apatemys. Whereas the M2 from Whitehead Creek differs from described Apatemys specimens (e.g., AMNH 56046) in features such as the size of the hypocone, and stylar development, it is considerably larger than upper molars that have been assigned to species. The Raben Ranch $\mathrm{m} 1$ (SDSM 10242) is of comparable size to the type and only known specimen of the late Uintan Apatemys downsi (LACM [CIT] 5202; $\mathrm{m} 1$ length $=2.5$ $\mathrm{mm}$; Gazin, 1958), and, although no upper teeth are known for $A$. downsi, there is nothing to suggest that the Whitehead Creek M2 (UMPC 14190) would be incompatible with the $\mathrm{m} 2$ of that species. Whereas the Raben Ranch $\mathrm{m} 1$ is morphologically similar to the $A$. downsi $\mathrm{m} 1$, the Raben Ranch specimen exhibits a somewhat more elongate anterobuccal crest running from the protoconid and a reduced paraconid when compared with $A$. downsi (Gazin, 1958, plate 13.9). However, without some understanding of intraspecific variation for $A$. downsi, the significance of this variation is dubious. Whether the Nebraska specimens represent a geographic and temporal range extension for $A$. downsi or represent a new species of Apatemys is presently unclear and must await further sampling. 


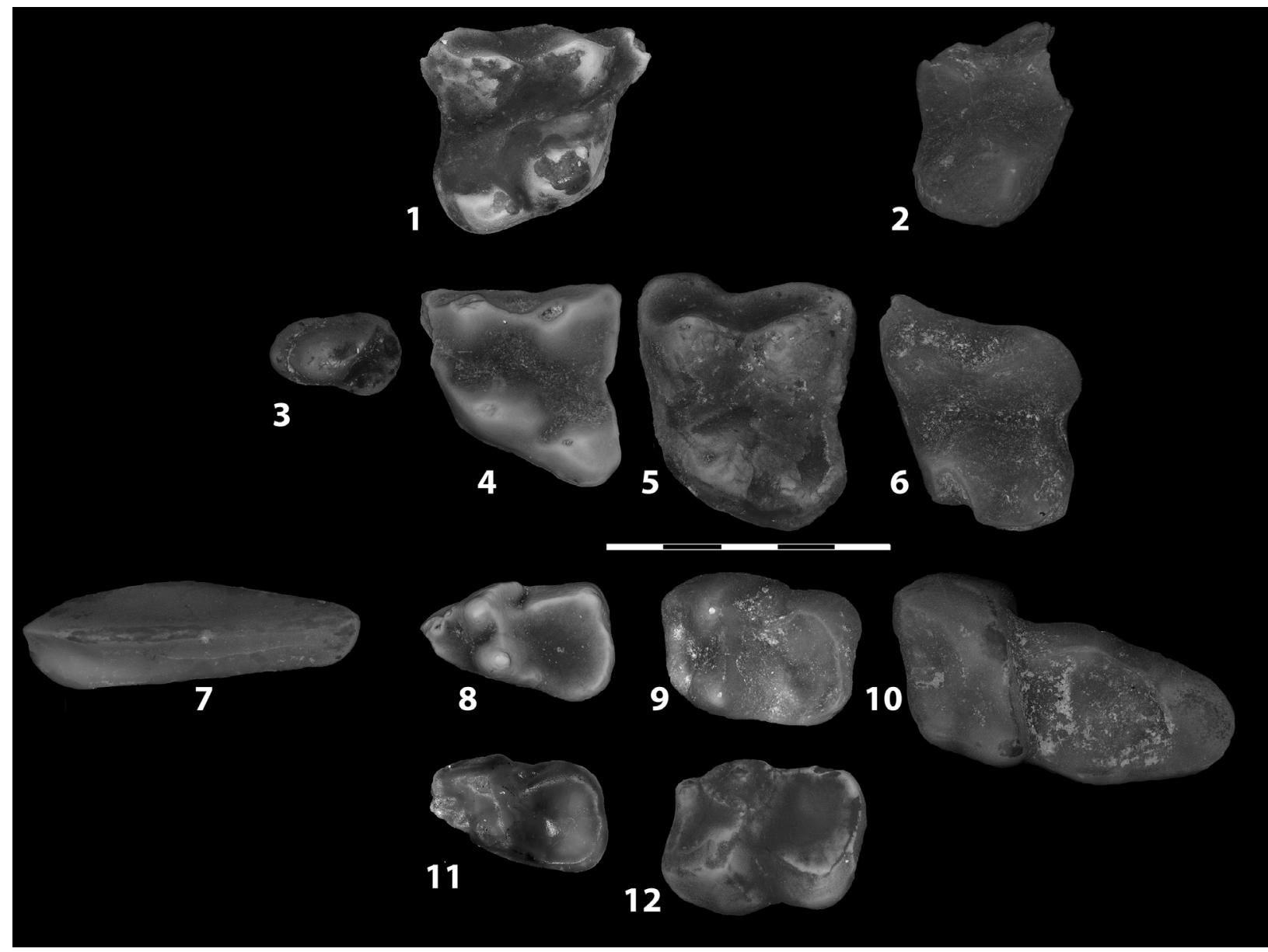

FIGURE 6. Teeth of Sinclairella dakotensis from Sioux County, Nebraska. 1, right M1 (UMPC 14860); 2, right M3 (UMPC 14864); 3, left P4 (SDSM 10392); 4, left M1 (UMPC 13937); 5, left M2 (UMPC 14862); 6, right M3 (UMPC 14863) (reversed); 7, left p2 (SDSM 10244) (reversed); 8, right m1 (UMPC 14861); 9, left m2 (UMPC 14866) (reversed); 10, left m3 (SDSM 10245) (reversed); 11, right m1 (UMPC 13938) and 12, left m2 (UMPC 13869). Teeth are shown in occlusal view. Divisions in scale are approximately $1 \mathrm{~mm}$.

Genus SINCLAIRELLA Jepsen, 1934 Sinclairella dakotensis Jepsen, 1934

Figure 6, Tables 1 and 2

Referred specimens. Left M1, UMPC 13937; right M1, UMPC 14860; left M2, UMPC 14862; right M3, UMPC 14863, 14864; left m1, UMPC 14270; right m1, UMPC 14861, 13938; left m2, UMPC 13869, 14866; right m2, UMPC 13601, 14865.

Horizon and locality. UMPC Loc \# MV 6335 "Whitehead Creek": UMPC 14270, 14860, 14866; UMPC Loc \# MV 6324 "Orella Road": UMPC 14861, 14865; UMPC Loc \# MV 6316 "Sand Creek": UMPC 13601, 13869, 13937, 13938, 14862, 14863, 14864. All localities are located within the middle Chadronian Peanut Peak Member, Chadron Formation.

Description. Two M1s are known from this sample, one from the Whitehead Creek locality and one from the Sand Creek locality. Both of these teeth are consistent with published descriptions of the M1 of Sinclairella (Jepsen, 1934; Clemens, 1964; West, 1973), although the two specimens differ slightly from each other. The right M1 from Whitehead Creek (UMPC 14860; Figure 6.1) shows little wear but exhibits moderate enamel damage on the cusp tips, the anterior border of the parastyle, and the postero-buccal corner of the tooth. The protocone is slightly larger than the two buccal trigon cusps, which are subequal in size and connected by a high centrocrista. A short preprotocrista runs antero-bucally from a point about halfway up the protocone to the anterior border of the tooth, where it joins with a small but prominent paraconule. The paraconule sits equidistant from the protocone and paracone and is separated from the paracone by a shallow groove. Directly anterior to the paracone is a well-developed parastylar shelf containing a 
small, worn parastyle. The parastylar shelf fades into the antero-buccal corner of the paracone, so that there is no stylar shelf along the antero-buccal margin of that cusp. Toward the postero-buccal corner of the paracone, the stylar shelf again appears and continues along the buccal edge of the tooth crown to its postero-buccal corner where it joins with the postmetacrista. Whereas the posterobuccal corner of the tooth is damaged, it is clear that the metastylar shelf is considerably smaller than the parastylar shelf. On the posterolingual corner of the tooth, the talon holds a large cuspate hypocone. This cusp is approximately one-third of the size of the protocone. The hypocone is separated from the protocone by a prominent groove.

The Sand Creek M1 (UMPC 13937; Figure 6.4) generally agrees morphologically with the specimen from Whitehead Creek, except that the tooth displays several less accentuated features. The bases of the talon cusps are less bulbous basally, giving the cusps a less conical appearance. This is particularly true of the protocone, which is somewhat bucco-lingually compressed. Distal to the protocone, the hypocone of the Sand Creek specimen, while prominent, is relatively smaller and more widely separated from the protocone. The paraconule is smaller in the Sand Creek specimen, and it is confluent with the paracone. Although the condition of the parastylar development cannot be evaluated due to damage to the antero-buccal corner of the tooth crown, the stylar development is not as well-developed in the Sand Creek specimen, judging from the buccal development of the stylar shelf. Whereas some of the difference between the specimens may result from the slightly more worn condition of the specimen from Sand Creek, we do not think that wear can fully account for these differences.

UMPC 14862 (Figure 6.5) is a left M2 from the Sand Creek anthills. Unlike the condition in M1, the three trigon cusps are subequal in size. There is a week preprotocrista running antero-bucally from the protocone and fading into the anterior edge of the tooth crown at about the midline of the tooth, before reaching a modest paraconule. The paraconule is adjoined to the antero-lingual border of the paracone. The paracone and metacone are connected by a stout centrocrista that forms a shallow " $u$ " along the midline of the tooth. A short preparacrista angles antero-bucally from the paracone, and joins the anterior margin of the tooth crown. There is minor enamel damage to the postero-buccal margin of the tooth, but it appears that the postmetacrista is slightly longer than the preparacrista and terminates at the postero-buccal corner of the tooth. The buccal margin of the tooth contains a broad stylar shelf. This shelf follows the contours of the paracone and metacone, and thus reaches further buccally along these cusps, creating a shallow ectoflexus along the center of the buccal margin. Whereas the stylar shelf is welldeveloped, there are no clear styles projecting from it.

The postero-lingual corner of the M2 consists of a large talon. This shelf slopes toward the posterior margin of the tooth crown and dips cervically. The result is an undulating posterior crown border with the greatest cervical projection about midway between the lingual and buccal border of the talon and the greatest occlusal projections along the postero-lingual border of the tooth and directly posterior to the metacone. There is a small hypocone along the lingual margin of the talon.

There are two M3 specimens from the Sand Creek locality. UMPC 14863 (Figure 6.6) is complete but exhibits a weathered groove running occluso-cervically on the lingual surface of the protocone and minor enamel damage on the hypocone. The antero-buccal corner of UMPC 14864 (Figure 6.2) is missing. These teeth exhibit the same general pattern of the M3 of Sinclairella discussed by Jepsen (1934) with a reduced metacone, hypocone, and metastylar shelf compared with the other upper molars. The result is an M3, which is more triangular in outline than either of the other upper molars.

Although similar, the two M3s differ from each other in overall size, the relative development of the talon, and the relative size of the metacone. UMPC 14863 is approximately 20-30\% larger than UMPC 14864 (Table 2). Lingually, the larger specimen exhibits a broader talon with a small hypocone; the smaller specimen lacks a hypocone. Buccally, the larger specimen has a larger, more bulbous metacone. Whereas these features suggest that UMPC 14863 may be an M2, the lack of a metastylar lobe results in the characteristic postero-lingual taper of the buccal crown surface from parastyle to metacone and suggests that this tooth is an M3. While not a perfect indicator of tooth position, the lack of an interproximal wear facet posterior to the metacone adds additional evidence that this specimen is an M3.

One $\mathrm{m} 1$ was recovered from each of the three study areas. Of these three teeth, the crown of the Orella Road specimen (UMPC 14861; Figure 6.8 ) is in excellent condition, showing minimal wear 
and only minor enamel damage on the underside of the anterior-most point of the trigonid. The crown morphology of this tooth is consistent with that described for the type specimen of Sinclairella (Jepsen, 1934). The trigonid is antero-posteriorly elongate and narrows anteriorly. The protoconid and metaconid are subequal, and each cusp rises well above the height of the protolophid. The paraconid is virtually absent, existing as a small swelling on the tooth anterior and slightly buccal to the metaconid. A ridge of enamel runs anteriorly and slightly lingually from the protoconid where it broadens into a small cuspule at the anterior edge of the tooth crown. The talonid is broader than the trigonid and is deeply basined. The cristid obliqua originates at the postero-buccal corner of the tooth from a modest hypoconid. This crest borders the buccal margin of the talonid in a antero-posterior direction before curving slightly linguad to join the postvallid low along the postero-lingual margin of a high protoconid. Buccal to this juncture between the cristid obliqua and the protoconid is a strong hypoflexid, accentuated by a substantial posterobuccal extension of the protoconid. This extension increases down the cusp as it approaches the cervical margin of the tooth crown. The posterior talonid margin consists of a sharp, arcuate postcristid. The hypoconulid and metaconulid are not clearly present.

The other two m1s in this sample show varying degrees of wear and enamel damage. UMPC 14270, from the Whitehead Creek Locality, is heavily worn and exhibits enamel damage on the antero-lingual border of the trigonid. This tooth agrees with the Orella Road specimen in the majority of features. It differs from this specimen in possessing a trigonid and talonid that are equal in height, a less marked hypoflexid, and an interruption in the postcristid at the midline of the tooth. Each of these differences could be attributed to the advanced state of wear of the Whitehead Creek specimen. The specimen from Sand Creek (UMPC 13938; Figure 6.11) shows modest wear and enamel damage to the anterior and posterior crown borders. The Sand Creek specimen is consistent with the other two specimens but exhibits a slightly more prominent paraconid.

Sinclairella dakotensis $\mathrm{m} 2$ is represented in this sample by two specimens from the Sand Creek Locality (see UMPC 13869, Figure 6.12), one specimen from the Whitehead Creek locality (UMPC 14866; Figure 6.9), and one partial specimen from the Orella Road locality. These four specimens agree with each other in crown mor- phology and all are consistent with other descriptions of S. dakotensis (Jepsen, 1934; Scott and Jepsen, 1936; West, 1973). Of the four specimens, the left $\mathrm{m} 2$ from Whitehead Creek (UMPC 14866; Figure 6.9) is in the best condition and provides the basis of this description. The trigonid consists of four cusps, the metaconid being about the same size as the protoconid. Directly anterior to the metaconid is a small paraconid. As is the case with $\mathrm{m} 1$ there is a crest running from the protoconid to a small cuspule. However, on $\mathrm{m} 2$ this cuspule sits at the antero-buccal corner of the tooth, further mesiad than the paraconid and further buccad than the protoconid, thus giving the trigonid the characteristic "quadrilateral" appearance described by Jepsen (1934).

The talonid is broad and deeply basined. Of the talonid cusps, only the hypocone is clearly visible as a modest swelling at the postero-buccal border of the tooth. The cristid obliqua runs in an antero-lingual direction from the hypoconid to the postero-lingual corner of the protocone, where the crest joins the postvallid. The hypoflexid is marked. The posterior and lingual margin of the talonid is bordered by a continuous crest (postcristid, preentoconid cristid, postmetaconid cristid).

Remarks. First described from a crushed skull from the Chadron Formation of southwestern South Dakota (Jepsen, 1934), Sinclairella dakotensis is known from the Chadronian of Wyoming (West, 1973), Nebraska (Hough and Alf, 1956; Ostrander, 1987; this study), North Dakota (Pearson and Hoganson, 1995), and Saskatchewan (Storer, 1996; Meyer, 2007), the Orellan of South Dakota (West, 1973) and Colorado (Clemens, 1964), and the Arikareean of South Dakota (Simpson, 1985), Nebraska (Gunnell et al., 2008), and Oregon (Cavin and Samuels, 2012). The genus is also known from the Duchesnean of Saskatchewan (Sinclairella sp., Storer, 1996) and the Arikareean of Florida (Sinclairella simplicidens, Czaplewski and Morgan, 2015). Whereas there is variation in the expression of traits, such as the degree of complexity in M1, cusp development, and overall size of $\mathrm{M} 3$, the Sinclairella specimens collected from each of these three sampling localities are consistent with previous descriptions of $S$. dakotensis (e.g., Jepsen, 1934; Clemens, 1964).

\section{DISCUSSION}

Sampling from Chadronian-age localities of Sioux County, Nebraska, has yielded several, new apatemyid dental specimens, nearly doubling the known sample size of Sinclairella dakotensis from 
this region and documenting the persistence of the genus Apatemys into the Chadronian of Nebraska. Whereas the additional specimens of $S$. dakotensis are consistent with previous descriptions of the species (e.g., Jepsen, 1934; Clemens, 1964; West, 1973), they also exhibit minor variations. Variation in the expression of traits, such as the degree of stylar development and size of the hypocone on $\mathrm{M} 1$, talon development, and metaconid size in $\mathrm{M} 3$, and $\mathrm{m} 1$ paraconid size, provide better understanding of the range of variation within this poorly sampled species. At the same time, the recovery of Apatemys molars from the Whitehead Creek locality prompted further evaluation of an apatemyid $\mathrm{m} 1$ (SDSM 10242) from the temporally and geographically proximate Raben Ranch locality, and its allocation to the genus Apatemys.

This is not the first report of Apatemys from the Chadronian. The genus Apatemys is also known by a single M2 from Chadronian-age deposits of the Calf Creek locality, Cypress Hills Formation, Saskatchewan (Meyer, 2007). The M2 from Saskatchewan is considerably larger than the Nebraska specimen and almost certainly represents a different species. Thus, it is evident that two species of Apatemys persist into the Chadronian within the Great Plains faunal province after their extinction from the Rocky Mountains basins (Prothero, 1996b) and localities further to the west (Golz and Lillegraven, 1977; Walsh, 1991) during the Uintan.

The persistence of Apatemys in the Great Plains after its extinction elsewhere is consistent with the geographic and temporal range extensions of other taxa known to persist as relicts in Chadronian-age localities throughout the Great Plains. In addition to our allocation of an apatemyid specimen from Raben Ranch to the genus Apatemys, Raben Ranch has also produced specimens of the omomyid primate Chumashius (Ostrander, 1987), the ischyromyid rodent Leptotomus, and the cylindrodontid rodents Pseudocylindrodon cf. P. tobeyi and Jaywilsonomys (Ostrander, 1980). An additional omomyid primate, Mytonius, was described from the Chadronian-age Short Pine Hills of South Dakota (Krishtalka, 1978). Kinm (2013) described the sciuravid rodent Prolapsus, and Kinm and Tornow (2014) described two plesiadapiforms, the paromomyid plesiadapiform Ignacius, and a uintasoricine microsyopid from the Chadronian-age Medicine Pole Hills Formation, North Dakota. In addition to Apatemys (Meyer, 2007), the Chadronian-age Calf Creek fauna includes specimens of Leptotomus (Storer, 1996). Whereas it is possible that differences in sampling strategies are responsible for the perceived temporal persistence of taxa within the Great Plains after their extinctions in the Rocky Mountains basins, we think that this is unlikely, as these relict taxa fail to show up in wellsampled, Chadronian-age localities within the Rocky Mountains faunal province, such as Pipestone Springs, Montana (Tabrum et al., 1996), Flagstaff Rim, Wyoming (Emry and Korth, 1993, 2012) and Kings Canyon, Colorado (Lloyd and Eberle, 2012). This pattern of taxonomic persistence is best explained by the persistence of localized wet habitats in the Great Plains faunal province that essentially disappeared in the Rocky Mountains basins during the late Eocene.

The late Eocene of North America was a period of climate change during which cooler, drier environments prevailed and fueled faunal turnover and ecosystems transformation, as demonstrated by paleosols (e.g., Retallack, 2007), marine records of $\delta^{180}$ (Miller et al., 2009), and terrestrial fossil samples (e.g., Retallack, 1992; Zanazzi et al., 2007). However, analyses of chemical weathering and carbonate depths of late Eocene paleosols from Oregon, Montana, and Nebraska indicate that Rocky Mountain rain shadows produced considerably drier intermontane environments (Retallack, 2007). These cooler, drier intermontane basins are associated with a reduction in biotic diversity during the late Eocene, while Oregon and Nebraska (i.e., east and west of the Rocky Mountains basin) were wetter and warmer with increased biotic diversity. Studies of paleosols from east of the Rocky Mountains basins in South Dakota (Retallack, 1990, 1992) and Eastern Wyoming (Evanoff et al., 1992) indicate that at least some of these areas were warm, moist, closedcanopy forests during the late Eocene. Indeed, mammalian isotope data indicate that the mammalian ecosystems of Nebraska were more stable during this period (Zanazzi and Kohn, 2008), although this ecosystem stability appears to have been limited to drier habitats given a simultaneous reduction in wet habitats (Boardman and Secord, 2013). In light of these data, it is likely that the persistence of Apatemys, discussed herein, as well as the presence of a variety of relict or immigrant taxa in middle Chadronian deposits of Sioux County, Nebraska (e.g., Ostrander, 1980, 1987; Arbor and Tornow, 2015), are evidence that late Eocene tropical refugia existed in northwestern Nebraska. Analyses of phytoliths recovered from Chadronian deposits in Nebraska support this assertion, resulting in reconstructions of a rich environment with a 
canopy of palm trees and an understory of bamboos and herbaceous dicots (Strömberg, 2004). Ongoing analyses of middle Chadronian fossil samples from Sioux County, Nebraska contribute to better understanding broad patterns of small mammal diversity and paleoenvironmental change leading up to the Eocene-Oligocene transition.

\section{ACKNOWLEDGMENTS}

The authors wish to thank the U. S. Forest Service, Nebraska National Forests and Grasslands, and the State of Nebraska Bureau of Educational Lands and Funds for permissions to conduct research federal and State lands. We thank $A$. Kinm for numerous discussions of Chadronian faunas, M. Muñiz and $\mathrm{H}$. LaGarry for discussion of geology in the field, J. Cavin for providing data on Sinclairella from Oregon, B. Beasley for permit assistance on federal lands, and P. Speirs and R. Endacott for assistance with accessing State of Nebraska lands. We thank K. Moore for assistance with collections management at UMPC. Specimens for study and imaging were provided by the Geology Museum, South Dakota School of Mines and Technology and the University of Montana Paleontology Center. M.T. thanks Sarah, Sören, and Ida for their love, understanding, and support in the field and in the lab. T.A. thanks Asher, Verity, and Sage for their patience, humor, love, and support during fieldwork. Financial support for this project was provided by Marian University (T.A.), Des Moines University (IOER Grant \#2010-20; T.A.), and St. Cloud State University (Faculty Improvement Research Grant; M.T.). We gratefully acknowledge our anonymous reviewers and the handling editor, K. Claeson, for their considerable time, meticulous reviews, and thoughtful suggestions that improved this manuscript.

\section{REFERENCES}

Alf, R. 1962. A new species of the rodent Pipestoneomys from the Oligocene of Nebraska. Breviora, 172:1-7.

Arbor, T.C. and Tornow, M.T. 2015. Small mammals of the middle Chadronian (late Eocene) Whitehead Creek local fauna of Nebraska. Society of Vertebrate Paleontology Meeting Program and Abstracts, 2015: 80.

Bajpai, S., Kapur, V.V., Das, D.P., Tiwari, B.N., Saravanan, N., and Sharma, R. 2005. Early Eocene land mammals from Vastan Lignite Mine, District Surat (Gujarat), Western India. Journal of the Palaeontological Society of India, 50:101-113.

Beard, K.C. and Dawson, M.R. 2001. Early Wasatchian mammals from the Gulf Coastal Plain of Mississippi: biostratigraphic and paleobiogeographic implications; p. 75-94. In Gunnell, G.F. (ed.), Eocene Biodiversity: Unusual Occurrences and Rarely Sampled Habitats. Plenum Press, New York, New York.

Beard, K.C. and Dawson, M.R. 2009. Early Wasatchian mammals of the red hot Local fauna, uppermost Tuscahoma Formation, Lauderdale County, Mississippi. Annals of the Carnegie Museum, 78:193-243.

Boardman, G.S. and Secord, R. 2013. Stable isotope paleoecology of White River ungulates during the Eocene-Oligocene climate transition in northwestern Nebraska. Palaeogeography, Palaeoclimatology, Palaeoecology, 375:38-49.

Bown, T.M. and Schankler, D. 1982. A review of the Proteutheria and Insectivora of the Willwood Formation (lower Eocene), Bighorn Basin, Wyoming. Geological Survey Bulletin, 1523. United States Government Printing Office, Washington, D.C.

Cavin, J.L. and Samuels, J.X. 2012. The first record of an apatemyid from Oregon: Sinclairella dakotensis from the Turtle Cove Member of the John Day Formation. Journal of Vertebrate Paleontology, Program and Abstracts, 2012:76.

Clemens, W.A. 1964. Records of the fossil mammal Sinclairella, family Apatemyidae, from the Chadronian and Orellan. University of Kansas Publications, Museum of Natural History, 14:483-491.

Czaplewski, N.J. and Morgan, G.S. 2015. A late-surviving apatemyid (Mammalia: Apatotheria) from the latest Oligocene of Florida, USA. Peer J, 3:e1509. doi 10.7717/peerj.1509

Emry, R.J. 1992. Mammalian range zones in the Chadronian White River Formation at Flagstaff Rim, Wyoming; p. 106-115. In Prothero, D.R. and Berggren, W.A. (eds.), Eocene-Oligocene Climatic and Biotic Evolution. Princeton University Press, Princeton, New Jersey.

Emry, R.J. and Korth, W.W. 1993. Evolution in Yoderimyinae (Eomyidae: Rodentia) with new material from the White River Formation (Chadronian) at Flagstaff Rim, Wyoming. Journal of Paleontology, 67:10471057.

Emry, R.J. and Korth, W.W. 2012. Early Chadronian (late Eocene) rodents from the Flagstaff Rim area, central Wyoming. Journal of Vertebrate Paleontology, 32:419-432.

Estravis, C. 2000. Nuevos mamiferos del Eoceno inferior de Silveirinha (Baixo Mondego, Portugal). Coloquios de Paleontología, 51:281-311.

Evanoff, E., Prothero, D.R., and Lander, R.H. 1992. Eocene-Oligocene climatic change in North America: the White River Formation near Douglas, east-central Wyoming, p. 116-130. In Prothero, D.R. and Berggren, W.A. (eds.), Eocene-Oligocene Climatic and Biotic Evolution. Princeton University Press, Princeton, New Jersey.

Flannery, T.F. 1994. Possums of the World: A Monograph of the Phalangeroidea. Geo Productions, Sidney, Australia. 
Gazin, C.L. 1958. A review of the middle and upper Eocene primates of North America. Smithsonian Miscellaneous Collections, 136:1-112.

Gingerich, P.D. 1982. Labidolemur and Apatemys from the early Wasatchian of the Clark's Fork Basin, Wyoming. Contributions from the Museum of Paleontology, University of Michigan, 26:57-69.

Golz, D.J. and Lillegraven, J.A. 1977. Summary of known occurrences of terrestrial vertebrates from Eocene strata of southern California. Contributions to Geology, University of Wyoming, 15:43-64.

Gunnell, G.F. 1998. Mammalian fauna from the lower Bridger Formation (Bridger A, early middle Eocene) of the southern Green River Basin, Wyoming. Contributions from the Museum of Paleontology, The University of Michigan, 30:83-130.

Gunnell, G.F., Bown, T.M., Bloch, J.I., and Boyer, D.M. 2008. "Proteutheria"; p. 63-81. In Janis, C.M., Gunnell, G.F., and Uben, M.D. (eds.), Evolution of Tertiary Mammals of North America Volume 2. Cambridge University Press, New York, New York.

Guthrie, D.A. and Allen, V. 1974. Age of the Chadron anthill fauna from Nebraska. Journal of Mammalogy, 55:452.

Hough, J. and Alf, R. 1956. A Chadron mammalian fauna from Nebraska. Journal of Paleontology, 30:132-140.

Jepsen, G.L. 1934. A revision of the American Apatemyidae and the description of a new genus, Sinclairella, from the White River Oligocene of South Dakota. Proceedings of the American Philosophical Society, 74:287-305.

Kihm, A.J. 2013. Rodents from the Chadronian (latest Eocene) Medicine Pole Hills local fauna, North Dakota. Part 2. Ischyromyidae, Sciuravidae, Aplodontidae, Sciuridae and Heliscomyidae. Paludicola, 9:41-55.

Kinm, A.J. and Tornow, M.A. 2014. First occurrence of plesiadapiform primates from the Chadronian (latest Eocene). Paludicola, 9:176-182.

Korth, W.W. 1992. Cylindrodonts (Cylindrodontidae, Rodentia) and a new genus of eomyid, Paranamatomys, (Eomyidae, Rodentia) from the Chadronian of Sioux County, Nebraska. Transactions of the Nebraska Academy of Sciences, 19:75-82.

Krishtalka, L. 1978. Paleontology and geology of the Badwater Creek area, central Wyoming. Part 15. Review of the Late Eocene Primates from Wyoming and Utah, and the Plesitarsiiformes. Annals of the Carnegie Museum, 47:335-360.

LaGarry, H.E. and LaGarry, L.A. 1997. Geology of the Montrose, Orella, Wolf Butte, Roundtop, and Horn 7.5' USGS quadrangles, Sioux and Dawes Counties, Nebraska. University of Nebraska - Lincoln Conservation and Survey Division Open-File Report No. 48. University of Nebraska, Lincoln, Nebraska.

Lloyd, K.J. and Eberle, J.J. 2012. A late Eocene (Chadronian) mammalian fauna from the White River For- mation in Kings Canyon, northern Colorado. Rocky Mountain Geology, 47:113-132.

Ma, A. 1998. Early Eocene micromammals in the San Jose Formation, San Juan Basin, New Mexico. Unpublished PhD Dissertation, The University of New Mexico, Albuquerque, New Mexico, USA.

Marandat, B. 1989. Mammiferes nouveaux de l'llerdien des Corbieres et du Minervois (Bas-Languedoc, France). Palaeovertebrata, 19:161-167.

Marsh, O.C. 1872. Preliminary description of new Tertiary mammals, Part II. American Journal of Science, Series 3, 4:202-224.

Matthew, W.D. 1909. The Carnivora and Insectivora of the Bridger Basin, middle Eocene. Memoirs of the American Museum of Natural History, 9:289-567.

McKenna, M.C. 1963. Primitive Paleocene and Eocene Apatemyidae (Mammalia, Insectivora) and the primate-insectivore boundary. American Museum Novitates, 2160:1-39.

Meyer, T. 2007. Chadronian "insectivores" of the Cypress Hills, Saskatchewan. MS Thesis, University of Saskatchewan, Saskatoon, Saskatchewan, Canada.

Miller, K., Wright, J.D., Katz, M.E., Wade, B.S., Browning, J.V., Cramer, B.S., and Rosenthal, Y. 2009. Climate threshold at the Eocene-Oligocene transition: Antarctic ice sheet influence on ocean circulation. Geological Society of America Special Papers, 452:169-178.

Ostrander, G.E. 1980. Mammalia of the early Oligocene (Chadronian) Raben Ranch local fauna of northwestern Nebraska. MS Thesis, South Dakota School of Mines and Technology, Rapid City, South Dakota, USA.

Ostrander, G.E. 1985. Correlation of the early Oligocene (Chadronian) in northwestern Nebraska. Dakoterra, 2:205-231.

Ostrander, G.E. 1987. The early Oligocene (Chadronian) Raben Ranch local fauna, northwest Nebraska: Marsupialia, Insectivora, Dermoptera, Chiroptera, and Primates. Dakoterra, 3:92-104.

Pearson, D.A. and Hoganson, J.W. 1995. The Medicine Pole Hills local fauna: Chadron Formation (Eocene: Chadronian), Bowman County, North Dakota. North Dakota Academy of Science Proceedings, 49:65

Prothero, D.R. 1996a. Magnetic stratigraphy of the White River Group in the high plains, p. 262-277. In Prothero, D.R. and Emry, R.J. (eds.), The Terrestrial Eocene-Oligocene Transition in North America. Cambridge University Press, New York, New York.

Prothero, D.R. 1996b. Magnetic stratigraphy and biostratigraphy of the middle Eocene Uinta Formation, Uinta Basin, Utah; p. 3-24. In Prothero, D.R. and Emry, R.J. (eds.), The Terrestrial Eocene-Oligocene Transition in North America. Cambridge University Press, New York, New York.

Prothero, D.R. and Swisher, III, C.C. 1992. Magnetostratigraphy and geochronology of the terrestrial EoceneOligocene transition in North America, p. 46-73. In 
Prothero, D.R. and Berggren, W.A. (eds.), EoceneOligocene Climatic and Biotic Evolution. Princeton University Press, Princeton, New Jersey.

Retallack, G.J. 1990. Soils of the Past. Unwin-Hyman, London.

Retallack, G.J. 1992. Paleosols and changes in climate and vegetation across the Eocene/Oligocene boundary, p. 382-398. In Prothero, D.R. and Berggren, W.A. (eds.), Eocene-Oligocene Climatic and Biotic Evolution. Princeton University Press, Princeton, New Jersey.

Retallack, G.J. 2007. Cenozoic paleoclimate on land in North America. Journal of Geology, 115:271-294.

Robinson, P. 1966. Fossil Mammalia of the Huerfano Formation, Eocene, of Colorado. Bulletin of the Peabody Museum of Natural History, Yale University, 21:1-95.

Russell, D.E., Godinot, M., Louis, P., and Savage, D.E. 1979. Apatotheria (Mammalia) de l'Éocène inférieur de France et de Belgique. Bulletin Museum National d'Histoire Naturelle, Paris, Séries 4, 1:203-242.

Scott, W.B. and Jepsen, G.L. 1936. The mammalian fauna of the White River Oligocene: Part I. Insectivora and Carnivora. Transactions of the American Philosophical Society, New Series, 28:1-153.

Silcox, M.T., Bloch, J.I., Boyer, D.M., and Houde, P. 2010. Cranial anatomy of Paleocene and Eocene Labidolemur kayi (Mammalia: Apatotheria), and the relationships of the Apatemyidae to other mammals. Zoological Journal of the Linnean Society, 160:773825.

Simpson, G.G. 1954. An apatemyid from the early Eocene of New Mexico. American Museum Novitates, 1654:1-4.

Simpson, W.F. 1985. Geology and paleontology of the Oligocene Harris Ranch Badlands, southwestern South Dakota. Dakoterra, 2:303-333.

Soligo, C. 2005. Anatomy of the hand and arm in Daubentonia madagascariensis: A functional and phylogenetic outlook. Folia Primatologia, 76:262300.

Storer, J.E. 1984. Mammals of the Swift Current Creek local fauna (Eocene: Uintan), Saskatchewan. Natural History Contributions, Saskatchewan Museum of Natural History, 7:1-58.

Storer, J.E. 1987. Dental evolution and radiation of Eocene and early Oligocene Eomyidae (Mammalia, Rodentia) of North America, with new material from the Duchesnean of Saskatchewan. Dakoterra, 3:108117.

Storer, J.E. 1996. Eocene-Oligocene faunas of the Cypress Hills Formation, Saskatchewan, p. 240-261.
In Prothero, D.R. and Emry, R.J. (eds.), The Terrestrial Eocene-Oligocene Transition in North America. Cambridge University Press, New York.

Strömberg, C.A.E. 2004. Using phytolith assemblages to reconstruct the origin and spread of grass-dominated habitats in the great plains of North America during the late Eocene to early Miocene. Palaeogeography, Palaeoclimatology, Palaeoecology, 207:239-275.

Tabrum, A.R., Prothero, D.R., and Garcia, D. 1996. Magnetostratigraphy and biostratigraphy of the EoceneOligocene transition, southwestern Montana, p. 278311. In Prothero, D.R. and Emry, R.J. (eds.), The Terrestrial Eocene-Oligocene Transition in North America. Cambridge University. Press, New York, New York.

Terry, D.O. 1998. Lithostratigraphic revision and correlation of the lower part of the White River group: South Dakota to Nebraska, p.15-37. In Terry, D.O., LaGarry, H.E., and Hunt, R.M. (eds.), Depositional Environments, Lithostratigraphy, and Biostratigraphy of the White River and Arikaree Groups (Late Eocene to Early Miocene, North America). Geological Society of America, Boulder, Colorado.

von Koenigswald, W., Rose, K.D., Grande, L., and Martin, R.D. 2005. First apatemyid skeleton from the lower Eocene Fossil Butte Member, Wyoming (USA), compared to the European apatemyid from Messel, Germany. Palaeontographica A, 272:149-169.

von Koenigswald, W. and Schierning, H.-P. 1987. The ecological niche of early Tertiary apatemyids - extinct group of mammals. Nature, 326:595-596.

Walsh, S.L. 1991. Eocene mammal faunas of San Diego County, p.161-178. In Abbott, P.L. and May, J.A. (eds.), Eocene Geologic History San Diego Region. Pacific Section SEPM, Los Angeles, California.

West, R.M. 1973. Review of the North American Eocene and Oligocene Apatemyidae (Mammalia: Insectivora). Texas Tech University Museum Special Publication, 3:1-42.

West, R.M. and E.G. Atkins. 1970. Additional middle Eocene (Bridgerian) mammals from Tabernacle Butte, Sublette County, Wyoming. American Museum Novitates, 2404:1-26.

Zanazzi, A. and Kohn, M.J. 2008. Ecology and physiology of White River mammals based on stable isotope ratios of teeth. Palaeogeography, Palaeoclimatology, Palaeoecology, 257: 22-37.

Zanazzi, A., Kohn, M.J., McFadden, B.J., and Terry, Jr., D.O. 2007. Large temperature drop across the Eocene-Oligocene transition in central North America. Nature, 445:639-642. 